\title{
POLITIK HUKUM PIDANA NASIONAL DALAM MENGHADAPI ERA TEKNOLOGI INFORMASI DIHUBUNGKAN DENGAN UNDANG-UNDANG NOMOR 11 TAHUN 2008 TENTANG INFORMASI DAN TRANSAKSI ELEKTRONIK
}

\author{
Mia Amalia \\ Dosen Tetap Fakultas Hukum Universitas Suryakancana Cianjur \\ E-mail: amalia.amalia84@gmail.com
}

\begin{abstract}
The world civilization has been indicated by advancement phenomenon of information technology as well as globalization in every aspect of life. The word "globalization" started in the begining of the $20^{\text {th }}$ century; at the time of transportation and electronic revolution spreading out and accelerating trades among nations, as well as the improvement and the speed of goods and service traffic.
\end{abstract}

Keywords: national criminal law politic; information and electronic transaction.

\begin{abstract}
Abstrak
Peradaban dunia pada masa kini dicirikan dengan fenomena kemajuan teknologi informasi dan globalisasi yang berlangsung hampir di semua bidang kehidupan. Apa yang disebut dengan globalisasi pada dasarnya bermula dari awal abad ke-20, yakni pada saat terjadi revolusi transportasi dan elektronika yang menyebarluaskan dan mempercepat perdagangan antar bangsa, disamping pertambahan dan kecepatan lalu lintas barang dan jasa.
\end{abstract}

Kata Kunci: Politik hukum pidana nasional, informasi dan transaksi elektronik.

\section{A. PENDAHULUAN}

Dalam rangka menghadapi pembukaan pasar regional oleh AFTA pada tahun 2003 dan dalam rangka menghadapi liberalisasi perdagangan WTO pada tahun 2010, negara-negara yang aktif terlibat dalam praktik perdagangan internasional mulai membentuk instrument hukum yang mengatur masalah perilaku perusahaan dan individu-individunya agar tidak menyalahkan market powert-nya. ${ }^{1}$ Deregulasi dalam liberalisasi diharapkan dapat menciptakan mekanisme pasar yang sehat. $^{2}$

Aspek-aspek pendukung seperti ilmu pengetahuan, teknologi informasi,

1 Juwono Sudarsono, Globalisasi Ekonomi Dan Demokrasi Indonesia, Artikel Dalam Majalah Prisma, No 8 Tahun XIX 1990, LP3ES, Jakarta, hlm. 9.

2 Mas Wigrantoro Roes Setiyadi, Implikasi Multi-Dimensional Dari Kebijakan Telematika Indonesia, Makalah Pada Seminar Dies Natalis Fisipol UGM Yogyakarta ke-46, 19 September 2001, hlm. 4. 
infrastuktur dan sistem sosial yang berkembang secara dinamis mengikuti proses globalisasi merupakan aspek pendukung dalam pembentukan instrument hukum tersebut. ${ }^{3}$

Menurut Didik J. Rachbini, ${ }^{4}$ teknologi informasi dan media elektronika dinilai sebagai simbol pelopor, yang akan mengintegrasikan seluruh sistem dunia, baik dalam aspek sosial, budaya, ekonomi dan keuangan. Dari sistem-sistem kecil lokal dan nasional, proses globalisasi dalam tahun-tahun terakhir bergerak cepat, bahkan terlalu cepat menuju suatu sistem global. Dunia akan menjadi "global village" yang menyatu, saling tahu dan terbuka, serta saling bergantung satu sama lain.

Penggabungan komputer dengan telekomunikasi melahirkan suatu fenomena yang mengubah konfigurasi model komunikasi konvesional, dengan melahirkan kenyataan dalam dimensi ketiga. Jika dimensi pertama adalah kenyataan keras dalam kehidupan empiris (biasa disebut hard reality), dimensi kedua merupakan kenyataan dalam kehidupan simbolik dan nilai-nilai yang dibentuk (dipadankan dengan sebutan soft reality), maka dengan dimensi ketiga dikenal kenyataan maya (virtual reality) yang melahirkan suatu format masyarakat lainnya. ${ }^{5}$
Oleh karena itu, proses pembangunan harus diupayakan agar berjalan secara teratur, dan berkelanjutan (sustainable development) di setiap sektor. Sebagaimana dikemukakan oleh Soerjono Soekanto bahwa ${ }^{6}$ "Pembangunan merupakan perubahan terencana dan teratur yang antara lain mencakup aspek-aspek politik, ekonomi, demografi, psikologi, hukum, intelektual maupun teknologi."

Berkenaan dengan pembangunan teknologi, dewasa ini seperti kemajuan dan perkembangan teknologi informasi melalui Internet (Interconnection Network), peradaban manusia dihadapkan pada fenomena baru yang mampu mengubah hampir setiap aspek kehidupan manusia. Pembangunan di bidang teknologi informasi (dengan segala aspek pendukungnya) diharapkan akan membawa dampak positif bagi kehidupan manusia, yang pada khirnya akan bermuara pada terciptanya peningkatan kesejahteraan umat manusia. ${ }^{7}$

Kemajuan dan perkembangan teknologi, khususnya telekomunikasi, multimedia dan teknologi informasi (telematika) pada akhirnya dapat merubah tatanan organisasi dan hubungan sosial kemasyarakat. Hal ini tidak dapat dihindari, karena fleksibilitas dan kemampuan telematika dengan cepat

$3 \quad$ Ibid., hlm. 9.

4 Didik J Rachbini, Mitos Dan Implikasi Globalisasi, Catatan Untuk Bidang Ekonomi Dan Keuangan, Pengantar Edisi Indonesia Dalam Hirst, Paul Dan Grahame Thompson, Globalisasi Adalah Mitos, Jakarta, Yayasan Obor, 2001, hlm. 57.

5 Ashadi Siregar, Negara Masyarakat Dan Teknologi Informasi, Maklah Pada Seminar Teknologi Informasi, pemberdayaan masyarakat Dan Demokrasi, Yogyakarta, 19 September 2001.

6 Soerdjono Soekanto, Kegunaan Sosiologi Hukum Bagi Kalangan Hukum, Alumni, Bandung, 1986, hlm. 11.

7 Sudarto, Kapita Selekta Hukum Pidana, Alumni, Bandung, 1981, hlm. 93. 
memasuki berbagai aspek kehidupan manusia. $^{8}$

Bagi sebagian orang munculnya fenomena ini telah mengubah perilakunya bersamaan dengan manusia lainnya, yang terus menjalar kebagian-bagian lain dari sisi kehidupan manusia, sehingga memunculkan adanya norma-norma baru, nilai-nilai baru, dan sebagainya. ${ }^{9}$

Menurut Soerjono Soekanto ${ }^{10}$, kemajuan di bidang teknologi akan berjalan bersama dengan munculnya perubahan-perubahan di bidang kemasyarakatan. Perubahan-perubahan di dalam masyarakat dapat mengenai nilai sosial, kaidah-kaidah sosial, pola-pola perilakuan, organisasi, dan susunan lembaga kemasyarakatan.

Pesatnya perkembangan teknologi itu telah membentuk masyarakat informasi internasional, termasuk di Indonesia. Sehingga, satu sama lain menjadikan belahan dunia ini sempit dan berjarak pendek. Berbisnis pun begitu mudahnya, seperti membalikkan telapak tangan saja. $^{11}$

Pembentukan peraturan perundangan di era teknologi informasi ini harus dilihat dari berbagai aspek. ${ }^{12}$ Misalnya dalam hal pengembangan dan pemanfaatan rule of law dan internet, jurusdiksi dan konflik hukum, pengakuan hukum terhadap dokumen serta tanda tangan elektronik, perlindungan dan privasi konsumen, cybercrime, pengaturan konten dan caracara penyelesaian sengketa domain. ${ }^{13}$

Kemajuan teknologi yang ditandai dengan munculnya penemuan-penemuan baru seperti internet, merupakan salah satu penyebab munculnya perubahan sosial, di samping penyebab lainnya seperti bertambah atau berkurangnya penduduk, pertentangan-pertentangan dalam masyarakat, terjadinya pemberontakan atau revolusi di dalam tubuh masyarakat itu sendiri. ${ }^{14}$ Hal yang sama dikemukakan oleh Satjipto Raharjo bahwa,

"Dalam kehidupan manusia banyak alasan yang dapat dikemukakan sebagai penyebab timbulnya suatu perubahan di dalam masyarakat, tetapi perubahan dalam penerapan hasil-hasil teknologi modern dewasa ini banyak disebut-sebut sebagai salah satu sebab bagi terjadinya perubahan sosial."

Oleh karena itu menurut Didik J. Rachbini, ${ }^{15}$ dalam pelaksanaannya sistem teknologi terpaksa berbenturan dengan nilai-nilai moral. Dampak negatif yang ditimbulkan oleh produk teknologi informasi belum mencapai tingkat kemapanan.

\footnotetext{
8 Mas Wigrantoro Roes Setiyadi, Implikasi Multi-Dimensional Dari Kebijakan Telematika Indonesia, Makalah Pada Seminar Dies Natalis Fisipol UGM Yogyakarta ke-46, 19 September 2001, hlm. 45. Ibid., hlm. 48.

Soerdjono Soekanto, Pokok-Pokok Sosiologi Hukum, Rajawali Pers, Jakarta, 1980, hlm. 87-88. Ibid., hlm. 89.

Syamsul Muarif, menunggu Lahirnya Cyber Law dalam http//www.cybernews.cbn.net.id, Akses tanggal 26 Desember 2004, 90.

Ibid., hlm. 94.

Lihat Soerdjono Soekanto, Sosiologi Suatu Pengantar, Rajawali, Jakarta, 1992, hlm. 352.

Didik J Rachbini, Op.Cit.
} 
Walaupun kemajuan teknologi menimbulkan dampak negatif, tetapi justru bagi sebagian orang, kemajuan teknologi seperti internet banyak memberikan manfaat, baik dari segi keamanan maupun kenyamanan. Batas ruang dan waktu menjadi hilang atau tipis dengan adanya jaringan komputer internet. ${ }^{16}$

Pada mulanya jaringan internet hanya dapat digunakan oleh lingkungan pendidikan (perguruan tinggi) dan lembaga penelitian. Kemudian tahun 1995, internet baru dapat digunakan untuk publik. ${ }^{17}$ Beberapa tahun kemudian, Tim Beners-Lee mengembangkan aplikasi world wide web (www) yang memudahkan orang untuk mengakses informasi di internet. Setelah dibukanya internet untuk keperluan publik semakin banyak muncul aplikasi-aplikasi bisnis internet. ${ }^{18}$

Aplikasi bisnis yang berbasiskan teknologi internet ini mulai menunjukan adanya aspek finansial. ${ }^{19}$ Misalnya, internet digunakan sebagai sarana untuk memesan/reservasi tiket (pesawat terbang, kereta api), hotel, pembayaran tegihan telepon, listrik, dan sebagainya. Hal ini mempermudah konsumen dalam menjalankan aktivitas/transaksi bisnisnya. ${ }^{20}$ Konsumen tidak perlu keluar rumah dan antri untuk memperoleh layanan yang diinginkan karena dapat dilakukan di dalam rumah, begitu pula tingkat keamanannya yang relative lebih terjaga. ${ }^{21}$

Umumnya suatu masyarakat yang mengalami perubahan akibat kemajuan teknologi, banyak melahirkan masalahmasalah sosial. Hal itu terjadi karena kondisi masyarakat itu sendiri yang belum siap menerima perubahan atau dapat pula karena nilai-nilai masyarakat yang telah berubah dalam menilai kondisi lama sebagai kondisi yang tidak lagi dapat diterima. ${ }^{22}$

Sebagai contoh, penggunaan mesinmesin tekstil modern untuk menggantikan alat pemintalan benang manual dapat mengakibatkan timbulnya Pemutusan Hubungan Kerja (PHK) besar-besaran. Hal ini menyebabkan tingginya tingkat pengangguran meningkat dan memicu meningkatnya tindak kejahatan. ${ }^{23}$ Dampak negatif terjadi pula akibat pengaruh penggunaan media internet dalam kehidupan masyarakat dewasa ini. Melalui media internet beberapa jenis tindak pidana semakin mudah untuk dilakukan seperti, tindak pidana pencemaran nama baik, pornografi, perjudian, pembobolan rekening, perusakan jaringan cyber (hacking), penyerangan melalui virus (virus attack) dan sebagainya. ${ }^{24}$

Sebagaimana dikemukakan oleh Roy Suryo, seorang pakar teknologi informasi,

\footnotetext{
16 Budi Rahardjo, Pernak Pernik Peraturan Dan Pengaturan Cyberspace Di Indonesia, 2003, http//www. budi.insan.co.id, hlm. 2, akses tanggal 24 Desember 2004.

17 Ibid.

18 Ibid.

19 Ibid.

20 Majalah Tempo, Rubrik Teknologi Informasi, edisi 24 Juni 2001.

21 Ibid.

22 Horton, Paul B Dan Chester L Hunt, Sosiologi, Erlangga, Jakarta, 1984, hlm. 237.

23 Ashadi Siregar, Negara Masyarakat Dan teknologi Informasi, Makalah Pada Seminar Teknologi Informasi, pemberdayaan masyarakat Dan Demokrasi, Yogyakarta, 19 September 2001, hlm. 49.

24 Ibid., hlm. 50
} 
dalam penelitiannya yang dikutip oleh Harian Kompas menyatakan: ${ }^{25}$

"Kejahatan cyber (cyber crime) kini marak di lima kota besar di Indonesia dan dalam taraf yang cukup mengkhawatirkan serta dilakukan oleh para hacker yang rata-rata anak muda yang kelihatannnya kreatif, tetapi sesungguhnya mereka mencuri nomor kartu kredit melalui internet."

Kata "cyber" yang berasal dari kata "cybernetics", merupakan suatu bidang ilmu yang merupakan perpaduan antara robotik, matematika, elektro, dan psikologi yang dikembangkan oleh Norbert Wiener di tahun 1948. ${ }^{26}$ Salah satu aplikasi dari cybernetics adalah di bidang pengendalian (robot) dari jarak jauh. Dalam hal ini tentunya yang diinginkan adalah sebuah kendali yang betul-betul sempurna (perfect control). Karenanya Budi Rahardjo berpendapat bahwa sedikit mengherankan jika kata "cyberspace" yang berasal dari kata "cyber" tidak dapat dikendalikan. Cyberspace dapat diatur, meskipun pengaturannya membutuhkan pendekatan yang berbeda dengan cara yang digunakan untuk mengatur dunia nyata. ${ }^{27}$

Dalam makalah ini ada beberapa masalah yang dijadikan bahan permasalahan yaitu sebagai berikut:

1. Apakah hukum pidana Indonesia telah mampu mengantisipasi munculnya kejahatan-kejahatan tersebut,

2. Apakah undang-undnag pidana kita mampu menjerat pelaku tindak pidana yang dilakukan di dunia maya (cyber crimes)?

\section{B. PEMBAHASAN}

Sekalipun perangkat hukum seperti Kitab Undang-Undang Hukum Pidana (KUHP) sudah dimiliki Indonesia, namun peraturan itu masih belum cukup mampu menjerat pelaku tindak pidana di Internet. Apalagi dalam Pasal 1 KUHP disebutkan "tidak ada perbuatan pidana jika sebelumnya tidak dinyatakan dalam suatu ketentuan undang-undang." Artinya, pasal itu menegaskan kalau pelaku kejahatan Internet belum tentu dapat dikenakan sanksi pidana. ${ }^{28}$

Selain benturan dengan Pasal 1 KUHP, kesulitan untuk menjerat pelaku tindak pidana yang dilakukan di dunia maya berkaitan dengan masalah pembuktian. ${ }^{29}$ Hukum positif mengharuskan adanya alat bukti, saksi, petunjuk, keterangan ahli serta terdakwa dalam pembuktian. Sedangkan dalam hal kejahatan terkait dengan teknologi informasi sulit dilakukan pembuktiannya. $^{30}$

Mengenai hal ini Soedjono

Dirdjosisworo menyatakan: ${ }^{31}$

"Perubahan dan penyesuaian sosial serta perkembangan teknologi

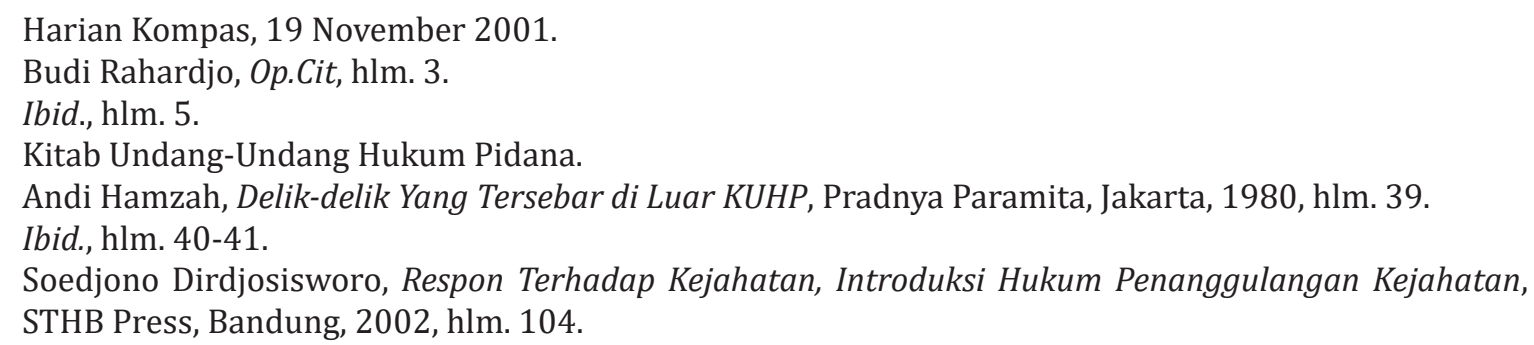


selama setengah abad sejak 1958 (UU No. 73/58) demikian pesatnya, dan kepesatan perkembangan sosial dan teknologi serta semakin berpengaruhnya globalisasi yang terus didorong oleh teknologi informasi dan komunikasi sangatlah terasa bahwa Kitab Undang-Undang Hukum Pidana sudah sejak lama tidak mampu secara sempurna mengakomodasi dan mengantisipasi kriminalitas yang meningkat, baik kualitatif maupun kuantitatif dengan jenis, pola dan modus operandi yang tidak terdapat dalam Kitab Undang-Undang Hukum Pidana (contoh menonjol adalah Cyber Crime)."

\section{Cyber Crime Sebagai Bentuk Kejahatan Baru}

Istilah cybercrime saat ini merujuk pada suatu tindakan kejahatan yang berhubungan dengan dunia maya (cyberspace) dan tindakan kejahatan yang menggunakan komputer. $^{32}$ Ada ahli yang menyamakan antara tindak kejahatan cyber (cybercrime) dengan tindak kejahatan komputer, dan ahli yang membedakan di antara keduanya. ${ }^{33}$

Bila seseorang menggunakan komputer atau bagian dari Jaringan komputer tanpa seijin yang berhak, tindakan tersebut sudah tergolong pada kejahatan komputer. Keragaman aktivitas kejahatan yang berkaitan dengan komputer atau jaringan komputer sangat besar dan telah menimbulkan perbendaharaan bahasa baru, misalnya hacking, cracking, virus, time bomb, worm, troyan horse, logical bomb, spaming, hoax, dan lain-lain sebagainya. Masing-masing memiliki karakter berbeda dan implikasi yang diakibatkan oleh tindakannya pun tidak sama. $^{34}$

Andi Hamzah dalam bukunya aspek-aspek pidana di bidang komputer menyatakan bahwa kejahatan di bidang komputer secara umum dapat diartikan sebagai penggunaan komputer secara illegal. Pada dasarnya cybercrime meliputi semua tindak pidana yang berkenaan dengan informasi, sistem informasi itu sendiri serta sistem komunikasi yang merupakan sarana untuk penyampaian atau pertukaran onformasi itu kepada pihak lainnya. ${ }^{35}$

Bentuk kejahatan lainnya seperti pornografi dalam berbagai jenis dengan mudah dapat dilihat di ebberapa situs tertentu bahkan di beberapa websites dapat kita jumpai adanya ruang untuk melakukan perjudian, misalnya dalam situs www.altavista.com disuguhi apa yang dinamakan www.Iycos.com akan ditemukan berbagai bentuk perjudian dengan nama Kasino Games. ${ }^{36}$

\section{Perubahan Ketentuan Hukum Pidana Indonesia Sebagai Akibat Kemajuan Teknologi Informasi}

Dengan adanya Undang-Undang Nomor 11 Tahun 2008 tentang Informasi

\footnotetext{
32 Ibid., Ashadi Siregar, Negara Masyarakat Dan Teknologi... hlm. 29.

33 Ibid., hlm. 30-31.

34 Ibid., hlm. 34.

35 Lihat Andi Hamzah, Delik-delik Yang tersebar... hlm. 39.

36 Majalah Tempo, Rubrik Teknologi Informasi, Edisi 24 Juni 2001.
} 
dan Transaksi Elektronik, memperhatikan hal-hal sebagaimana dikemukakan di atas nampak jelas bahwa kebutuhan perundang-undangan baru yang mengatur mengenai kejahatan di dunia maya (cyber crime) masih belum efektif. ${ }^{37}$

Banyak Sarjana Hukum yang memberikan pengertian tentang politik hukum. Masing-masing sarjana memberikan pengertian bergantung pada sudut pandangnya masing-masing yang tentunya sangat dipengaruhi oleh latar belakang keilmuannya. ${ }^{38}$ Sarjana Politik akan lebih menonjolkan aspek politiknya pada saat memberikan definisi politik hukum, begitu pula dengan seorang Sarjana Hukum yang akan lebih mengendepankan aspek hukumnya dalam memberikan definisi politik hukum. ${ }^{39}$

"Namun dengan meyakini adanya persamaan substansif antar berbagai pengertian yang ada, studi ini mengambil pengertian bahwa politik hukum adalah legal policy yang akan atau telah dilaksanakan secara nasional oleh Pemerintah Indonesia yang meliputi: pertama, pembangunan hukum yang berintikan pembuatan dan pembaruan terhadap materi-materi hukum agar dapat sesuai dengan kebutuhan; kedua, pelaksanaan fungsi lembaga dan pembinaan para penegak hukum."
Mengacu pada pendapat di atas, maka dalam tulisan ini pengertian politik hukum dipahami sebagai suatu kajian terhadap perubahan yang harus dilakukan dalam hukum yang berlaku agar dapat memenuhi kebutuhan kehidupan masyarakat. ${ }^{41} \mathrm{Hal}$ ini sesuai dengan apa yang dikemukakan oleh Bellefroid, sebagaimana dikutip oleh Sugeng Istanto, bahwa Politik Hukum merupakan bagian dari Ilmu Pengetahuan Hukum yang membahas perubahan ius constitutum (hukum yang berlaku sekarang/ditetapkan) menjadi ius constituendum (hukum yang harus ditetapkan/dicita-citakan) untuk memenuhi kehidupan masyarakat. ${ }^{42}$

Beberapa faktor yang perlu diperhatikan dalam melaksanakan penyesuaian materi hukum sebagai konsekuensi terhadap perubahan perundang-undangan, yaitu: ius constitutum, perubahan masyarakat, dan ius constituendum. ${ }^{43}$

\section{Ius Constitutum (Hukum Yang Berlaku)}

Kitab Undang-Undang HUkum Pidana (KUHP) Indonesia merupakan salah satu produk hukum peninggalan jaman kolonial. Tetapi dalam perkembangannya beberapa materi Kitab Undang-Undang Hukum Pidana telah mengalami beberapa perubahan. ${ }^{44}$

KUHP yang berlaku hingga sekarang, ialah Wetboek van Strafrecht yang

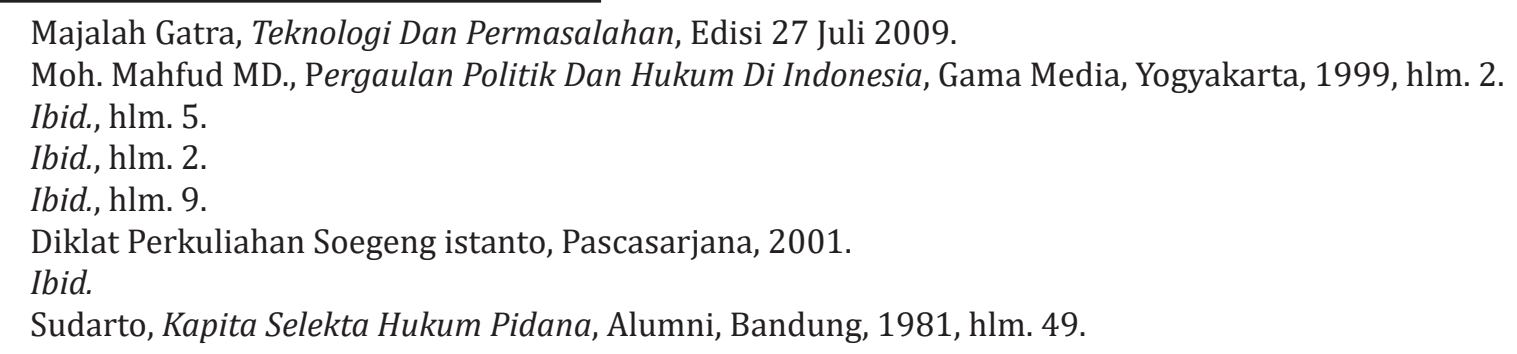


dituangkan dalam Koninklijk Besluit (K.B) tanggal 15 Oktober 1915 dan diundangkan dalam Saatsblad 1915 nomor 732, dan mulai berlaku pada tanggal 1 Januari 1918 untuk semua golongan penduduk. ${ }^{45}$

Kitab Undang-Undang Hukum Pidana berlaku atas dasar Aturan Peralihan Pasal II Undang-Undang Dasar 1945, dan mulai diperbaharui mulai tahun 1946 melalui Undang-undang Nomor 1 tahun 1946. selanjutnya, karena berbagai kebutuhan dan perkembangan masyarakat yang semakin cepat, maka dibuatlah beberapa undang-undang Pidana di luar Kitab Undang-Undang Hukum Pidana. Sekalipun demikian, tuntutan terhadap Hukum Pidana semakin hari semakin nyata. ${ }^{46}$

Dari pendapat yang dikemukakan oleh R. Iwa Kusuma Sumantri di atas jelaslah, bahwa diperlukan perubahan terhadap Kitab Undang-Undang Hukum Pidana Nasional. Hal ini tidak dapat ditundatunda lagi, bahkan telah diprediksi jauh sebelumnya. ${ }^{47}$

\section{Perubahan Masyarakat}

Perubahan kehidupan masyarakat pada intinya adalah perubahan nilai. Beberapa bidang kehidupan manusia yang juga mengalami perubahan, diantaranya: perubahan bidang hukum, politik, ekonomi, sosial budaya. Perubahanperubahan tersebut ada yang berdampak positif maupun negatif bagi kehidupan kemasyarakatan. Sehingga diperlukan kejelian untuk mempergunakan perubah- an ini menuju arah yang lebih baik bagi kesejahteraan umat manusia. ${ }^{48}$

Apabila kita perhatikan lebih dalam, ada beberapa faktor yang menyebabkan terjadinya perbahan (dalam arti luas), yaitu:

a. Pemikiran manusia. Akal budi yang diberikan tuhan pada manusia akan selalu berkembang dari waktu ke waktu, kondisi ini mengakibatkan manusia untuk senantiasa mempergunakan pemikirannya dalam segala aspek kehidupannya.

b. Kebutuhan/tuntutan manusia. Di satu sisi manusia selalu menginginkan agar kebutuhannya selalu terpenuhi, sementara dilain sisi manusia tidak akan pernah terpuaskan, kondisi ini menyebabkan manusia dengan berbagai usahanya berupaya agar kebutuhannya secara relatif dapat terpenuhi.

c. Cara hidup manusia. Perkembangan jaman selalu berdampak pada timbulnya berbagai perubahan dalam kehidupan manusia, termasuk di dalamnya cara hidup.

d. Teknologi (kemampuan cipta sarana). Semakin maju kehidupan manusia semakin meningkat pula kemampuan manusia dalam melahirkan teknologi.

e. Komunikasi dan transportasi. Kemajuan sarana komunikasi dan transportasi berakibat pada mudahnya interaksi antara satu tempat dengan tempat lain, negara-negara tidak lagi dibatasi

\footnotetext{
$45 \quad$ Ibid., hlm. 56.

46 Ibid., hlm. 58-59.

47 Ibid., hlm. 60.

48 Soerdjono Soekanto, Pokok-Pokok Sosiologi Hukum, Rajawali Pers, Jakarta, 1980, hlm. 39.
} 
oleh ruang dan waktu, semuanya terhubung dalam suatu jaringan global. ${ }^{49}$

Di samping itu, adanya berbagai perubahan dalam kehidupan masyarakat sebagai akibat kemajuan teknologi informasi (seperti: lahirnya internet) mengharuskan perlunya dilakukan berbagai penyesuaian. Kejahatankejahatan baru yang timbul sebagai akibat dari kemajuan teknologi informasi praktis sukar untuk dijerat dengan hanya mendasarkan pada ketentuan perundangundangan yang dibentuk dalam suasana serba tradisional/konvensional..$^{50}$

\section{Ius Constituendum (Hukum Yang Harus Ditetapkan)}

Guna menindaklanjuti tuntutan globalisasi serta kemajuan teknologi informasi yang menghendaki segala aktivitas manusia berlangsung dengan cepat, transparan, serta tanpa dibatasi oleh batas wilayah (borderless), maka dewasa ini pembaharuan hukum pidana sebagai bagian dari kebijakan hukum pidana telah diupayakan oleh berbagai pihak, baik dari kalangan praktisi hukum, akademisi maupun pemerintah melalui Rancangan Kitab Undang-Undang Hukum Pidana yang masih terus diolah. Dalam konteks Indonesia, pembaharuan hukum pidana dilakukan agar hukum pidana yang berlaku sesuai dengan nilai-nilai masyarakat Indonesia. ${ }^{51}$
Berkenaan dengan peran hukum pidana terhadap perkembangan teknologi informasi, maka perlu kiranya diperhatikan beberapa hal penting sebagai upaya penyempurnaan tehadap ketentuan Kitab Undang-Undang Hukum Pidana Nasional, yaitu: ${ }^{52}$

a. Dengan semakin maraknya kejahatankejahatan baru yang timbul sebagai akibat dari kemajuan teknologi informasi (cyber crime), maka dalam hal pembuktian sudah waktunya untuk dipikirkan kemungkinan adanya penambahan alat bukti lain yang berbasis teknologi, seperti alat bukti berupa surat elektronik (electronic mail) dan rekaman elektronik (electronic record);

b. Salah satu ciri kejahatan di dunia maya (cyber crime) adalah memanfaatkan jaringan telematika (telekomunikasi, media dan informatika) global. Aspek global menimbulkan kondisi seakan-akan dunia tidak ada batasnya (borderless). Keadaan ini mengakibatkan pelaku, korban serta tempat dilakukannya tindak pidana (locus delicti) terjadi di negara yang berbeda-beda. Oleh karena itu, untuk mengantisipasi hal tersebut maka daya berlaku Kitab Undang-Undang Hukum Pidana harus diperluas, sehingga tidak hanya mengacu pada asas/prinsip yang selama ini dianut dalam Pasal 2 Pasal 9 Kitab Undang-Undang Hukum

\footnotetext{
49 Doyle Paul Johnson, Teori Sosiologi Klasik dan Modern, Jilid I dan 2, Gramedia,Jakarta, 1988, hlm. 49.

50 Ibid., hlm. 49.

51 Tongat, Pidana Kerja Sosial Dalam Pembaharuan Hukum Pidana Indonesia, Jakarta, Djambatan, 2002, hlm. 20-21.

52 Ibid., hlm. 25.
} 
Pidana yaitu asas personal, asas teritorial, dan asas universal;

c. Untuk merumuskan dan menentukan perbuatan-perbuatan mana yang dapat dikenai sanksi pidana dalam dunia yang relatif baru dan bergerak cepat, tentu bukan merupakan pekerjaan yang mudah. Oleh karena itu, untuk menjerat pelaku tindak pidana yang melakukan kejahatan-kejahatan di dunia maya (cyber crime), dapat digunakan lembaga penafsiran hukum (interpretasi). Hal ini dimaksudkan untuk menghindarkan timbulnya kekosongan hukum.

\section{PENUTUP}

Era globalisasi dan teknologi informasi membawa pengaruh terhadap munculnya berbagai bentuk kejahatan yang sifatnya baru. Munculnya kejahatan baru (Cyber crime) merupakan suatu fenomena yang memerlukan penanggulangan secara cepat dan akurat.

Perubahan terhadap beberapa ketentuan yang etrdapat dalam KUHP merupakan salah satu cara yang dapat dipergunakan untuk mengatasi jenis kejahatan baru tersebut. Diharapkan dengan diberlakukannya berbagai perubahan dalam KUHP Nasional sebagai akibat dari timbulnya berbagai perubahan dalam kehidupan masyarakat, akan berdampak pada pulihnya kepercayaan masyarakat terhadap hukum.

Perubahan terhadap KUHP Nasional dapat dilakukan secara menyeluruh maupun parsial dengan menyusun undang-undang khusus di luar KUHP.

\section{DAFTAR PUSTAKA}

Ashadi Siregar, Negara Masyarakat Dan teknologi Informasi, Makalah Pada Seminar Teknologi Informasi, pemberdayaan masyarakat Dan Demokrasi, Yogyakarta, 19 September 2001.

Budi Rahardjo, Pernak Pernik Peraturan Dan Pengaturan Cyberspace Di Indonesia, 2003, http//www.budi. insan.co.id, hlm 2 akses tanggal 24 Desember 2004.

Didik J Rachbini, Mitos Dan Implikasi Globalisasi, Catatan Untuk Bidang Ekonomi Dan Keuangan, Pengantar Edisi Indonesia Dalam Hirst, Paul Dan Grahame Thompson, Globalisasi Adalah Mitos, Jakarta, Yayasan Obor, 2001.

Horton, Paul B Dan Chester L Hunt, Sosiologi, Erlangga, Jakarta, 1984.

Juwono Sudarsono, Globalisasi Ekonomi Dan Demokrasi Indonesia, Artikel Dalam Majalah Prisma, No 8 Tahun XIX 1990, LP3ES, Jakarta.

Mah Mahfud, MD, Pergaulan Politik Dan Hukum Di Indonesia, Gama Media, Yogyakarta, 1999.

Mas Wigrantoro Roes Setiyadi, Implikasi Multi-Dimensional Dari Kebijakan Telematika Indonesia, Makalah Pada Seminar Dies Natalis Fisipol UGM Yogyakarta ke-46, 19 September 2001. 
Soerdjono Soekanto, Pokok-Pokok Sosiologi Hukum, Rajawali Pers, Jakarta, 1980.

, Pokok-Pokok Sosiologi Hukum, Rajawali Pers, Jakarta, 1980. Kegunaan Sosiologi Hukum Bagi Kalangan Hukum, Alumni, Bandung, 1986.

Sudarto, Kapita Selekta Hukum Pidana, Alumni, Bandung, 1981.

Syamsul Muarif, Menunggu Lahirnya Cyber Law dalam http//www.cybernews. cbn.net.id, Akses tanggal 26 Desember 2004.

Soedjono Dirdjosisworo, Respon Terhadap Kejahatan, Introduksi Hukum Penanggulangan Kejahatan, STHB Press, Bandung, 2002.

Tongat, Pidana Kerja Sosial Dalam Pembaharuan Hukum Pidana Indonesia, Jakarta, Djambatan, 2002.

Undang-Undang Dasar 1945.

Kitab Undang-Undang Hukum Pidana.

Kitab Undang-Undang Hukum Acara Pidana.

Udang-Undang Nomor 11 Tahun 2008 tentang Informasi dan Transaksi Eleketronik.

Harian Kompas, 19 November 2001.
Majalah Tempo, Rubrik Teknologi Informasi, edisi 24 Juni 2001.

Diklat Perkuliahan Soegeng Istanto, Pascasarjana, 2001. 